\title{
Interferon Stimulated Gene 15 and Myxovirus Resistance 2 Genes are Upregulated during Early Pregnancy in Buffaloes
}

\author{
B.S. Pradeep Nag ${ }^{1}$, N. Arunmozhi ${ }^{2 *}$, T. Sarath ${ }^{2}$, S.A. Asokan², K. Vijayarani ${ }^{3}$, \\ G. Monica ${ }^{2}$, D. Gopikrishnan ${ }^{2}$ and K. Krishnakumar ${ }^{2}$ \\ ${ }^{1}$ National Dairy Research Institute, Karnal, India \\ ${ }^{2}$ Department of Veterinary Gynaecology and Obstetrics, ${ }^{3}$ Department of Animal \\ Biotechnology, MVC, Chennai, India \\ *Corresponding author
}

\section{A B S T R A C T}

\begin{tabular}{|c|}
\hline Keywords \\
\hline $\begin{array}{l}\text { Interferon } \\
\text { stimulated gene } 15 \text {, } \\
\text { Myxovirus } \\
\text { resistance 2, Heifer, } \\
\text { Pleuriparous } \\
\text { buffalo, } \\
\text { Upregulated }\end{array}$ \\
\hline Article Info \\
\hline $\begin{array}{l}\text { Accepted: } \\
15 \text { November } 2018 \\
\text { Available Online: } \\
10 \text { December } 2018\end{array}$ \\
\hline
\end{tabular}

Keywords

Interferon

stimulated gene 15 ,

Myxovirus

Pleuriparous

buffalo,

Upregulated

Article Info

15 November 2018

10 December 2018
The present study was done with the objective of finding the differential expression of ISG 15 and MX 2 genes in pregnant and non pregnant heifer and pleuriparous buffaloes. A total of 40 heifer and pleuriparous buffaloes were selected and divided into 2 experiments, Experiment I consisted of heifers (Group I and Group II) and Experiment II (Group III and Group IV) consisted of pleuiparous buffaloes. Group I and group III were considered as non inseminated control groups and group II and IVas treatment groups. Blood collection was done on days $0,14,16,18,20$ and 25 and peripheral blood mononuclear cells (PBMC) were isolated from which cDNA was synthesised for expression studies. Expression of ISG 15 and MX 2 genes were carried out by quantitative real-time PCR, relative expression was calculated by $2^{-\Delta \Delta C T}$ using GAPDH as housekeeping gene. Both the genes were upregulated between days 14 to 20 , reaching the peak by day 20 and decreased on day 25 to the values similar to day 14. A significantly $(\mathrm{P} \leq 0.01)$ higher relative expression of both ISG 15 and MX 2 genes was observed on days 18 and 20 post oestrum, in both the experimental groups.

\section{Introduction}

Pregnancy diagnosis in buffaloes is performed earliest by ultrasound on day 24 and by day 30 using rectal palpation. However, in both the techniques there is a chance of damage to the embryo due to improper handling (Purohit et al., 2010). In ruminants pregnancy is established via biochemical dialog between the conceptus and the maternal system during peri-implantation period by interferon tau $(\mathrm{IFN} \tau)$ which is secreted by elongating blastocyst that acts on the endometrium to alter the luteolytic signal, rescue the corpus luteum (CL) and ensures uninterrupted progesterone secretion (Mann and Lamming, 2006), stimulates the secretion of histotroph (Gray et al., 2006). IFN $\tau$ upregulates certain genes not only in the endometrium but also in systemic circulation, these genes are grouped under interferon stimulated genes (ISGs; Charleston and Stewart, 1993). The ISG'S viz. Interferon Stimulated Gene -15 (ISG-15), Myxovirus resistance gene 1 (MX-1), 
Myxovirus resistance gene $2(\mathrm{MX}-2)$ and 2'5'- oligoadenylate synthetase 1 (OAS-1), transcripts are upregulated between days 16 and 22 post-AI in dairy cattle (Pugliesi et al., 2014 and Gifford et al., 2007), 12 and 30 of pregnancy as compared to cyclic ewes (Yankey et al., 2001) and are implicated as an important factor in determining the uterine receptivity and conceptus development. Upregulation of such genes can be used as method to diagnose early pregnancy in the above said species. However, such reports on the expression profile of ISGs are scanty in buffaloes. The knowledge of expression of ISGs in pregnant and non pregnant buffaloes can throw light on the development of new methods for pregnancy diagnosis, either by profiling the ISGs or by detection of protein abundances that are transcribed by ISG's. Further this allows for earlier synchronization and shorter intervals between services or to inseminate in next immediate cycle. Considering the importance of ISGs in early pregnancy and their upregulation between days 16 and 22 of early pregnancy in cows and ewes, the present study was aimed to study the expression profile of two Interferon stimulated genes (ISGs) viz. ISG 15 and MX 2 in peripheral blood mononuclear cells (PBMC) of buffaloes.

\section{Materials and Methods}

A total of 40 apparently healthy buffalo heifers and pleuriparous buffaloes between age group of 2 and 10 years, over $280 \mathrm{~kg}$ body weight and free from reproductive abnormalities were selected for the study conducted at, Post Graduate Research Institute in Animal Sciences, Kattupakkam and Central Cattle Breeding Farm, Alamadhi. Selected animals were divided into the experiment I and experiment II consisting of nulliparous and pleuriparous buffaloes, respectively. Experiment I was further divided into group I and group II, Experiment II is divided into group III and group IV, group I and group III served as non-inseminated control.

All the experimental buffaloes irrespective of their stage of the cycle were synchronized using progesterone device TRIU-B ${ }^{\circledR}$ (Virbac Animal health, Mumbai, India) inserted intravaginally (day 0) and kept in situ for 9 days; Inj. Cloprostenol sodium (Pragma ${ }^{\circledR}$ ) $(500 \mu \mathrm{g})$ was administered intramuscularly on day 8post TRIU-B ${ }^{\circledR}$ insertion and the animals of group II and group IV were inseminated on 72 and $96 \mathrm{hrs}$ after administration of Inj. Cloprostenol sodium. Inj. Buserelin acetate $10 \mu \mathrm{g}$,a synthetic analogue of gonadotropin-releasing hormone $(\mathrm{GnRH})$ was administered at the time of the first insemination.

\section{PBMC isolation, RNA extraction and cDNA synthesis from peripheral blood}

Whole blood was collected from jugular venipuncture in an EDTA vacutainer on days 0 (day of insemination), 14, 16, 18, 20 and 25 post insemination for harvesting PBMC using Histopaque- $1077^{\circledR}$ solution (Sigma Aldrich, USA) and used immediately or stored in RNA latter ${ }^{\circledR}$ solution (Sigma Aldrich, USA)at- $80^{\circ} \mathrm{C}$ until the RNA was extracted. RNA was extracted using TRIzol ${ }^{\circledR}$ LS reagent (Ambion, Fischer Scientific, USA) as per manufacturer's instructions. Breifly, To the pellet, $750 \mu 1$ of TRIzol $^{\circledR}$ LS reagent was added, mixed well and incubated for 5 minutes at room temperature, chloroform $(200 \mu \mathrm{l})$ was added and incubated for 10 minutes at room temperature. The contents were centrifuged at $12,000 \mathrm{rpm}$ for 15 minutes at $4^{\circ} \mathrm{C}$. The upper aqueous phase was separated and equal volume of ice-chilled isopropanol was added and kept at $-20^{\circ} \mathrm{C}$ over night. This mixture was centrifuged at $12000 \mathrm{rpm}$ for 10 minutes at $4{ }^{\circ} \mathrm{C}$ to pellet the RNA. The supernatant was then discarded, the pellet was washed twice with 70 per cent ethanol and the pellet was air 
dried. The RNA pellet was resuspended in 20 $\mu l$ of nuclease free water. The quality and quantity of the RNA was estimated at $\mathrm{A}_{260 / 280}$ in the nano drop. The samples with 260/280 ratio of 1.9 and above were considered for cDNA synthesis (reverse transcription) using oligo dt primers with initial concentration of $1 \mu \mathrm{g}$ of total RNA from each sample using the High capacity cDNA synthesis kit (Applied Biosystems, USA) based on the following manufacturer's instructions of $20 \mu \mathrm{l}$ final volume.

\section{Quantitative real time PCR}

PCR conditions for each gene were optimized by semi-quantitative PCR using $1 \mu \mathrm{L}$ of cDNA, Green Master Mix and primers (10 $\mathrm{pM})$. Following optimization, the presence of a single product was confirmed on a $2.5 \%$ agarose gel by electrophoresis. Primer pair sequences along with optimized annealing temperatures are presented in Table 1.

Quantitative real time PCR (qRT-PCR) was per-formed on eppendroff qPCR master cycler using KiCqStart ${ }^{\circledR} \quad$ SYBR ${ }^{\circledR}$ Green $\quad$ qPCR ReadyMix $^{\mathrm{TM}}$ (Sigma, Invitrogen, USA). For each sample and gene transcript, a total reaction volume of $15 \mu \mathrm{L}$ was prepared containing $1 \mu \mathrm{L}$ of cDNA, $1 \mu \mathrm{L}$ each of $(5 \mathrm{pM})$ forward and reverse primer, SYBR green master mix $(7.5 \mu \mathrm{L})$ and rest of the volume adjusted with Nuclease free water. A nontemplate control was also run in duplicate. The house keeping gene used in the study was GAPDH. The qRT-PCR analysis was performed under following thermocyclic conditions: N-Glycosylase (UNG) inactivation at $50^{\circ} \mathrm{C}$ for 2 minutes, Initial denaturation at $95{ }^{\circ} \mathrm{C}$ for 10 minutes, Denaturation at $95{ }^{\circ} \mathrm{C}$ for $30 \mathrm{sec}$ Annealing at $64{ }^{\circ} \mathrm{C}$ for 1 minute, Extension at $72{ }^{\circ} \mathrm{C}$ for 15 minutes and Final Extension at $72^{\circ} \mathrm{C}$ for 1 minute. To prevent acquisition of smaller non-specific products, a melting curve analysis was performed. The efficiency of the qRT-PCR reactions was similar between the gene of interest and housekeeping gene. $\Delta \Delta \mathrm{Ct}$. method was used to analyze the relative expression. $2-\Delta \Delta \mathrm{Ct}$ value gave the relative quantification of expressed genes (Schmittgen and Livak, 2008). The results are expressed as relative expression compared to day 0 of non-bred control and pregnant animals. Obtained data was statistically analysed using ANOVA by SPSS statistics 20.0 (International Business Machine (IBM) corp., Chicago, USA).

\section{Results and Discussion}

\section{ISG-15 gene expression}

The relative expression (mean $\pm \mathrm{SE}$ ) of ISG 15 pregnant and control heifer and pleuriparous buffaloes are presented in Figure 1 and 2, respectively. In control animals, no significant difference was observed in the relative expression of ISG 15 between different days, whereas in pregnant animals the difference in relative expression on days 18 and 20 was significantly $(\mathrm{P} \leq 0.01)$ higher compared to other days.

\section{MX-2 gene expression}

The relative expression (mean \pm SE) of MX 2 in control and pregnant heifer and pleuriparous buffaloes are presented in figure 3 and 4, respectively. In control heifer and pleuriparous buffaloes there were no significant difference in the relative expression of MX 2 between different days. In pregnant heifers, significantly $(\mathrm{P} \leq 0.01)$ higher relative expression of MX 2 was noticed between all days except days 14 and 25 which were similar. However, in pleuriparous buffaloes, the difference in relative expression on days 18 and 20 was significant $(\mathrm{P} \leq 0.01)$ and on days 14, 16 and 25 were non significant. MX2 mRNA expression in PBMCs increased gradually from day 14 to 20 and reached peak 
by day 20 compared with day 0 in both primiparous and pleuriparous buffaloes. Relative expression of MX 2 mRNA levels in PBMC was above the arbitrary threshold of 2.0 from day 14 to 20 of pregnancy and that of control animals were low on all days below the arbitrary threshold value of 2.0.
In a similar study, Kose et al., (2014) have reported 5.8 fold increase in expression of MX2 mRNA on day 18 following AI in PBMC of cattle. Kose et al., (2016) have reported significant increase in MX 2 mRNA levels on day 15 after insemination in pregnant ewes.

Table.1 Details of primers used for real time quantification

\begin{tabular}{|c|l|l|c|c|}
\hline Sl. No & \multicolumn{1}{|c|}{ Primer } & \multicolumn{1}{|c|}{ Sequence (5' to 3') } & $\begin{array}{c}\text { Product } \\
\text { size }\end{array}$ & Reference \\
\hline $\mathbf{1}$ & $\begin{array}{l}\text { ISG-15-F } \\
\text { ISG-15-R }\end{array}$ & $\begin{array}{l}\text { GAAGGGAGGCCCATGGAT } \\
\text { CCCTTCGTGAGGCCGTATT }\end{array}$ & $56 \mathrm{bp}$ & Jain et al., 2012 \\
\hline $\mathbf{2}$ & $\begin{array}{l}\text { MX-2-F } \\
\text { MX-2-R }\end{array}$ & $\begin{array}{l}\text { GCACAGCAAGCTCTCTACGA } \\
\text { GCAAAACCCAGAAGGACTGC }\end{array}$ & $76 \mathrm{bp}$ & $\begin{array}{c}\text { Designedfrom } \\
\text { PrimerblastNCBI }\end{array}$ \\
\hline $\mathbf{3}$ & $\begin{array}{l}\text { GAPDH-F } \\
\text { GAPDH-R }\end{array}$ & $\begin{array}{l}\text { GTCTTCACTACCATGGAGAAGG } \\
\text { TCATGGATGACCTTGGCCAG }\end{array}$ & 197bp & Berisha et al., 2002 \\
\hline
\end{tabular}

Fig.1 Relative expression of ISG 15on different days post-oestrumin pregnant and non-bred control Heifer buffaloes

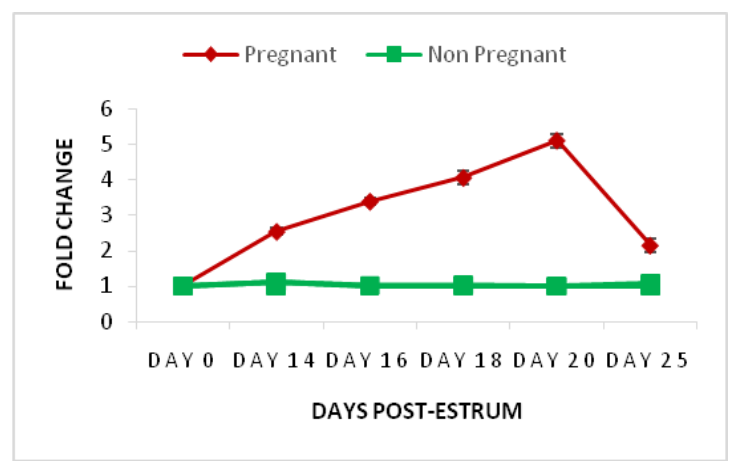

Fig.2 Relative expression of ISG 15on different days post-oestrumin pregnant and non-bred control pleuriparous buffaloes

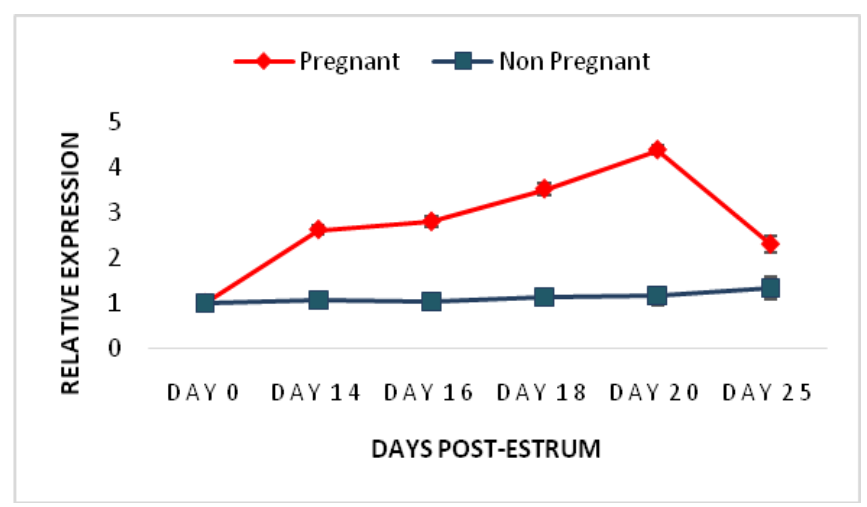


Fig.3 Relative expression of MX2 on different days post-oestrumin pregnant and non-bred control Heifers buffaloes

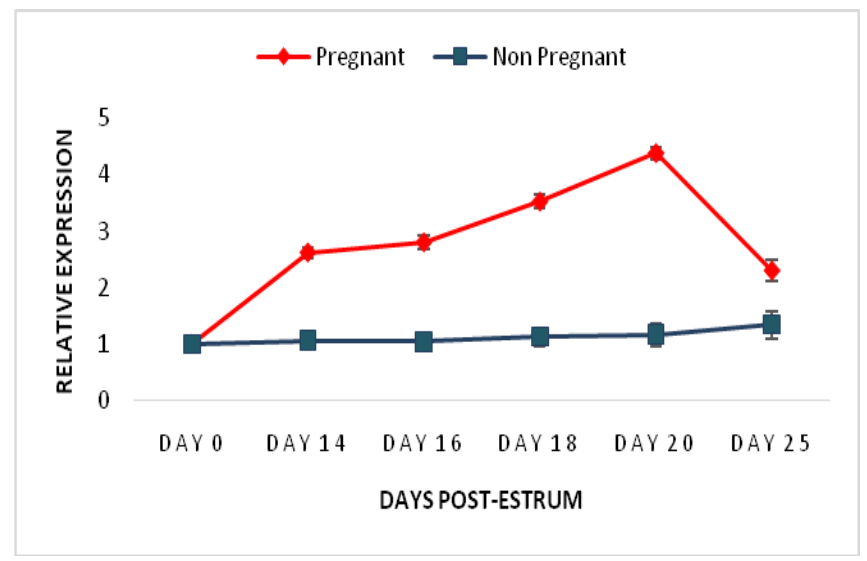

Fig.4 Relative expression of MX2 on different days post-oestrumin pregnant and non-bred control Heifers buffaloes

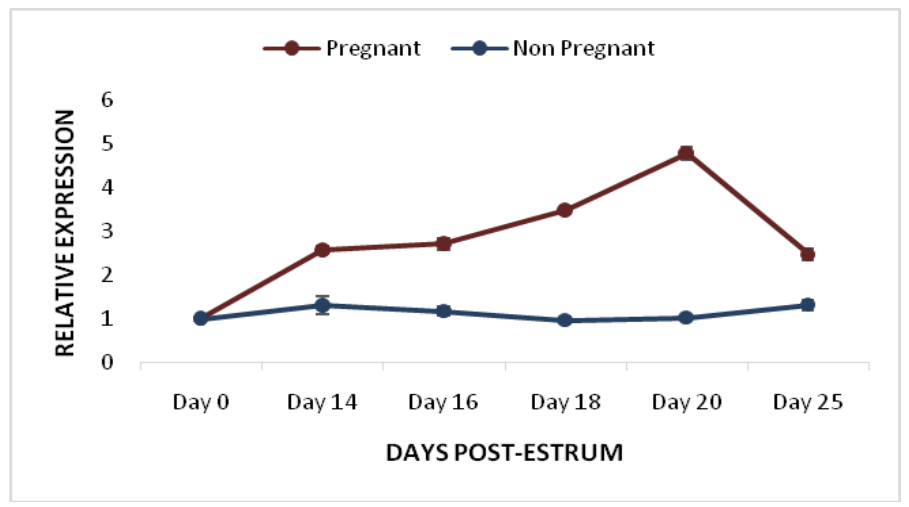

\section{ISG 15 gene expression}

The results obtained in the present study was in line with the observations of by Pugliesi et al., (2014) who also reported a progressive increase in ISGs from day 15 to 20 post insemination and a sharp decrease by day 22 in cattle. Around 6.97 fold higher expression of ISG was reported by Kose et al., (2014) by day 18 in cattle. Matsuyama et al., (2012) reported that average ISG 15 mRNA expression in PBMCs on day 18, 20, 25 was significantly higher in pregnant cattle, with higher expression of ISG 15 on day 18 in pregnant animals after non surgical embryo transfer. Han et al., (2006) have reported higher expression of ISG 15 mRNA levels from days 17 to 25 with maximum expression on day 18. Kose et al., (2016) reported higher expression of ISG $15 \mathrm{mRNA}$ levels from day 15 to 23 and reduced expression from day 23 to 25. Kizaki et al., (2013) reported higher expression of ISG 15 from days 14 to 21 post insemination that declined by day 28.In the present study and in the earlier reports, the abundance of ISG transcripts until day 22 was consistent, which was correlated to the profile of embryonic IFN $\tau$ secretion in ruminants. This indicated that the presence of viable conceptus stimulated expression of ISGs in PBMC in a rapid fashion following the initiation of conceptus elongation and during the period of luteolysis blockage in pregnant cow (Miagawa et al., 2013). Significantly 
higher expression of ISG 15 was observed in the present study from days 16 to 20 . This indicated that the presence of IFN $\tau$ in the endometrium stimulated significantly higher ISG 15 expression from day 16 to 20 , when its concentration was more in the uterine endometrium of buffaloes (Sarath, 2010). The increased expression of ISG 15 in the PBMCs during day 14 to 25 was supported by the study of Matsuyama et al., (2012) who have reported that intra uterine infusion of the IFN $\tau$ in the non pregnant cyclic ewes increased the expression of ISG 15 from day 18 to 25 postoestrus. The quantity of IFN $\tau$ infused had a positive correlation with the expression of ISG 15 in PBMCs. Thus the increase in the expression pattern from day 14 till 20 could be justified with the fact that the magnitude of increase in ISG $15 \mathrm{mRNA}$ expression in PBMC is due to the amount of IFN $\tau$ secretion and conceptus elongation (Matsuyama et al., 2012). Hence based on this concept, the conceptus produced IFN $\tau$ could be monitored by ISG 15 mRNA expression in PBMCs, thereby providing a powerful non invasive tool to evaluate embryonic mortality. Moreover reports in cow suggested that significant increase in ISG 15 expression was seen only from day 18 as the IFN $\tau$ reaches its peak by only day 17 in cattle (Bartol et al., 1985) but in the present report we have observed significantly higher expression from day 16 onwards in primiparous buffaloes. This was more likely due to one day earlier expression of IFN $\tau$ by buffalo conceptus than cow (Sarath, 2010) causing significantly increased concentration by day 16 and dependent increase in relative expression of ISG 15 in PBMCs in pregnant cows (Green et al., 2010). ISG 15 expression in ewe had shown significant difference from day 15 to 20 (Kose et al., 2016) which is supported by the report that increased expression of IFN $\tau$ gene in sheep was seen from day 13 onwards with significantly higher expression after day 15 (Miagawa et al., 2013). Hence, the significant difference in relative expression of ISG 15 observed from day 16 onwards in the present study falls between day 15 and 18 of ewe and cow, respectively.

\section{MX2 gene expression}

In the present study the expression of MX2 in pregnant heifers and pleuriparous buffaloes has been studies. Similarly Kizaki et al., (2013) reported higher expression of MX 2 on day 21 than day 0. Miagawa et al., (2013) and Pugliesi et al., (2014) reported higher degree of expression of MX 2 in PBMCs from day 15 post AI, reached peak on day 20 and decreased rapidly until day 22 and progressively decreased until day 45 in pregnant cows. Green et al., (2010) have reported higher expression on day 18 in pregnant cows.MX2 mRNA expression levels at four hrs after IFN $\tau$ treatment were positively correlated with the dose of IFN $\tau$ administered into uterus (Matsuyama et al., 2012) which further correlates to the presence of elongating embryo. Kose et al., (2016) demonstrated increased expression of MX2 in PBLs by intrauterine administration of IFN $\tau$ lasted for approximately $10 \mathrm{hrs,} \mathrm{suggesting}$ that the continuous supply of IFN $\tau$ was necessary for continuous expression of interferon stimulated genes which was not present in non pregnant or in early embryonic mortality. The higher expression of MX 2 in pregnant animals from day 14 to 25 was supported by the fact that the elongating blastocyst secreted increased amount of IFN $\tau$ which coincides with the days of increased expression of MX 2 gene. The peak expression was found on day 20, a time when the conceptus is synthesising large quantities of IFN $\tau$ (Thatcher et al., 1994).

In conclusion, the present study demonstrates that the interferon stimulated genes (ISG 15 and MX 2) are upregulated in heifer and pleuriparous pregnant buffaloes and the 
expression in heifers is more than the pleuriparous animals. Further studies are needed for identification of proteins transcribed by these genes, which if upregulated can be used for the diagnosis of pregnancy as early as 18 to 20 days beyond doubt.

Note: the present work is part of Master of Veterinary Science thesis submitted to Tamil Nadu Veterinary and Animal Sciences University.

\section{Acknowledgments}

Authors are grateful to Dr. Kulasekar, Project Investigator, AICRP, New Delhi sponsored scheme "Nutritional and Physiological approaches for enhancing reproductive performance in animals" for the financial assistance provided for this research.

\section{References}

Bartol, F.F., R.M. Roberts, F.W. Bazer, G.S. Lewis, J.D. Godkin and W.W. Thatcher, 1985. Characterization of proteins produced in vitro by peri-attachment bovine concept uses. Biol. Reprod., 32:681-693. http://europepmc. org/ abstract $/ \mathrm{med} / 3995135$

Charleston, B. and J.H. Stewart, 1993. An interferon-induced $\mathrm{Mx}$ protein: cDNA sequence and high-level expression in the endometrium of pregnant sheep. Gene, 137(2): 327-331.https://www. sciencedirect.com/science/article/pii/03 78111993900293?via\%3Dihub

Gifford, C.A., K. Racicot, D.S. Clark, K.J. Austin, T.R. Hansen, M.C. Lucy, C.J. Davies and T.L. Ott,2007. Regulation of interferon-stimulated genes in peripheral blood leukocytes in pregnant and bred, nonpregnant dairy cows. $J$. Dairy Sci., 90:274-280 https://www. sciencedirect.com/science/article/pii/S0
022030207726280

Gray, C.A., C.A. Abbey, P.D. Beremand, Y. Choi, J.L. Farmer, D.L. Adelson, T.L. Thomas, F.W. Bazer and T.E. Spencer, 2006. Identification of endometrial genes regulated by early pregnancy, progesterone, and interferon tau in the ovine uterus. Biol. Reprod., 74(2): 383394.https://academic.oup.com/biolrepro d/article/74/2/383/2666985

Green, J.C., C.S. Okamura, S.E. Poock and M.C. Lucy, 2010. Measurement of interferon-tau (IFN- $\tau$ ) stimulated gene expression in blood leukocytes for pregnancy diagnosis within 18-20d after insemination in dairy cattle. Anim. Reprod. Sci., 121(1): 24-33. https://www.sciencedirect.com/science/ article/pii/S037843201000309X

Han, H., K.H. Austin, L.A. Rempel and T.R. Hansen, 2006. Low blood ISG15 mRNA and progesterone levels are predictive of non-pregnant dairy cows. J. Endocrinol., 191(2): 505512.http://joe.endocrinologyjournals.org/content/191/2/505.short

Kizaki, K., A. Shichijo-Kizaki, T. Furusawa, T. Takahashi, M. Hosoe and K. Hashizume, 2013. Differential neutrophil gene expression in early bovine pregnancy. Reprod. Biol. Endocrinol., 11(1): 1. https://rbej. biomedcentral.com/articles/10.1186/147 7-7827-11-6

Kose, M., M. Gorgulu, M.S. Kaya, N. Aydilek, F. Bozkaya and T. Bayril, 2014. Expression profiles of interferontau stimulated genes (ISGs) in peripheral blood leucocytes (PBLs) and milk cells in pregnant dairy cows. Kafkas Universitesi Veteriner Fakultesi Dergisi, 20: 189-194. http:// vetdergikafkas.org/uploads/pdf/pdf_KV FD_1522.pdf

Kose, M., M.S. Kaya, N. Aydilek, I. Kucukaslan, T. Bayril, S. Bademkiran 
and Z. Kiyma, 2016. Expression profile of interferon tau-stimulated genes in ovine peripheral blood leukocytes during embryonic death. Theriogenology, 85(6): 1161-1166. https://www.sciencedirect.com/science/ article/pii/S0093691X15006706

Mann, G.E. and G.E. Lamming, 2006. Timing of prostaglandin $F_{2 \alpha}$ release episodes and oxytocin receptor development during luteolysis in the cow. Anim. Reprod. Sci., 93: 328-336. https://www. sciencedirect.com/science/article/pii/S0 378432005002393

Matsuyama, S., T. Kojima, S. Kato and K. Kimura, 2012. Relationship between quantity of IFNT estimated by IFNstimulated gene expression in peripheral blood mononuclear cells and bovine embryonic mortality after AI or ET. Reprod. Biol. Endocrinol., 10(1): 1. https://rbej.biomedcentral.com/articles/1 0.1186/1477-7827-10-21

Miagawa B.T., M.R. Franca, Y.N. Paiya, M.L. Olivera, E. Lopes, A.M.G. Diza, F.S. Mesquita, G. Pugliesi and M. Binelli, 2013. Presence of conceptus modulates expression of interferon tau stimulated genes in peripheral blood immune cells of pregnant and nonpregnant beef cows. proceedings of the $27^{\text {th }}$ annual meeting of Brazilian Embryo Technology Society.

Pugliesi, G., B.T. Miagawa, Y.N. Paiva, M.R. França, L.A. Silva and M. Binelli, 2014.
Conceptus-induced changes in the gene expression of blood immune cells and the ultrasound-accessed luteal function in beef cattle: how early can we detect pregnancy? Biol. Reprod., 91(4): 95. https://academic.oup.com/ biolreprod/article/91/4/95,\%201$12 / 2434333$

Purohit, G., 2010. Methods of Pregnancy Diagnosis In Domestic Animals: The Current Status. Webmed Central Reproduction, 1(12):WMC001305. http://www.webmedcentral.com/article_ view/1305

Sarath, T., 2010. Studies on expression profile of interferon- $\tau$ and embryonic development with reference to maternal recognition of pregnancy in buffalo. Ph.D., thesis submitted to Indian Veterinary Research institute, Bareilly, India. pp: 58-61.

Thatcher, W.W., M.D. Meyer and G. DanetDesnoyers, 1994. Maternal recognition of pregnancy. J. Reprod. Fertil. (Suppl.), 49: 15-28. http://europepmc. org/abstract/med/7623310

Yankey, S.J., B.A. Hicks, K.G. Carnahan, A.M. Assiri, S.J. Sinor, K. Kodali, J.N. Stellflug and T.L. Ott, 2001. Expression of the antiviral protein $\mathrm{Mx}$ in peripheral blood mononuclear cells of pregnant and bred, non-pregnant ewes. $J$. Endocrinol., 170(2): R7-R11. http://joe. endocrinology-journals.org/ content/170/2/R7.short

\section{How to cite this article:}

Pradeep Nag, B.S., N. Arunmozhi, T. Sarath, S.A. Asokan, K. Vijayarani, G. Monica, D. Gopikrishnan and Krishnakumar, K. 2018. Interferon Stimulated Gene 15 and Myxovirus Resistance 2 Genes are Upregulated during Early Pregnancy in Buffaloes. Int.J.Curr.Microbiol.App.Sci. 7(12): 1755-1762. doi: https://doi.org/10.20546/ijcmas.2018.712.204 